精巣の硬さを指標とした精子形成能の新規定量的評価

一精子形成不全ハムスターを用いて一

\title{
A New Quantitative Method for Evaluating Spermatogenesis Based on Measurements of the Testis Hardness : A Study Using a Hamster Model with Experimental Cryptorchidism
}

\author{
小川健司 (学生会員) $)^{\mathrm{a} *}$, 富塚大輔 ${ }^{\mathrm{a}}$, 吉池美紀 ${ }^{\mathrm{b}}$, 野澤資悪利 ${ }^{\mathrm{b}}$, 中澤龍斗 ${ }^{\mathrm{b}}$, 佐藤陽子 ${ }^{\mathrm{c}}$, 森川康 \\ 英 ${ }^{\mathrm{d}}$, 岩本晃明 $\mathrm{e}$, 大西公平 ${ }^{\mathrm{a}}$ \\ a 慶應義塾大学理工学部 \\ $\mathrm{b}$ 聖マリアンナ医科大学腎泌尿器外科 \\ c 東亜大学医療学部医療工学科 \\ $\mathrm{d}$ 国際医療福祉大学病院小児外科 \\ $\mathrm{e}$ 国際医療福祉大学病院リプロダクションセンター
}

Kenji Ogawa ${ }^{\mathrm{a}}$, Daisuke Tomizuka ${ }^{\mathrm{a}}$, Miki Yoshiike ${ }^{\mathrm{b}}$, Shiari Nozawa ${ }^{\mathrm{b}}$, Ryuto Nakazawa ${ }^{\mathrm{b}}$, Yoko Sato $^{\mathrm{c}}$, Yasuhide Morikawa $^{\mathrm{d}}$, Teruaki Iwamoto ${ }^{\mathrm{e}}$, Kouhei Ohnishi ${ }^{\mathrm{a}}$

${ }^{a}$ Faculty of Science and Technology, Keio University

${ }^{\mathrm{b}}$ Development of Urology, St. Marianna University School of Medicine

${ }^{c}$ Department of Medical Technology, Faculty of Allied Health Science, University of East Asia

${ }^{d}$ Department of Pediatric Surgery, International University of Health and Welfare Hospital

${ }^{\mathrm{e}}$ Center for Infertility and IVF, International University of Health and Welfare Hospital

\begin{abstract}
Background and Aims : Non-obstructive azoospermia (NOA) is one of the most serious causes of male infertility. Microdissection testicular sperm extraction (MD-TESE) is a first-line therapy of NOA ; however, sperm retrieval rate from MDTESE differs substantially between surgeons and is generally insufficient. To develop a new accessible method to identify seminiferous tubules with sperm in real time during MD-TESE, we have made a hypothesis that the hardness of seminiferous tubule wall is available as a quantitative index for the presence of sperm. In this study, as a first step, we determined the stiffness of the testis from an animal model of NOA using a measuring system that we designed.

Methods : Male Syrian hamster with bilateral experimental cryptorchidism was used as a NOA model. Stiffness of the testis was evaluated with two different indices of stiffness value : $K_{j}$ (the stiffness value in a small interval) and $\widetilde{K}$ (the mean of $K_{j}$ values) by using an indentation instrument with a micro force sensor.

Results : Hamster testis was confirmed to be valid as a dynamic model for physical measurements by checking the dependency of stiffness and viscosity on the reaction force generated in indentation procedure. Both stiffness values of the testis with cryptorchidism were significantly decreased compared with those of the control testis.

Conclusion : The results suggest that our system is useful for quantitative evaluation of testis stiffness. Testis hardness has promise for a new index for spermatogenesis. As the next step, we need this approach to permit measurement for seminiferous tubules.
\end{abstract}

Key words

Male Infertility, Non-Obstructive Azoospermia, Motion Control, Biomechanics

\footnotetext{
*慶應義塾大学理工学部

干 223-8522 神奈川県横浜市港北区日吉 3-14-1

kenji@sum.sd.keio.ac.jp

受付 2017 年 5 月 13 日；採択 2017 年 8 月 31 日
} 


\section{1. 序論}

男性不妊症の認知度は産婦人科医師でさえ十分で なく，特に無精子症の場合には男性不妊の精査もさ れずに絶対不妊を言い渡されることもある。なかで も, 精巣自体の造精機能障害による非閉塞性無精子 症（non-obstructive azoospermia：NOA）は最も治療が 困難な重症疾患で, 男性不妊症の約 10\%, 無精子症 の $60 \%$ を占める ${ }^{1)}$. NOA は従来, 非配偶者間人工授 精しか治療手段がないとされていたが, 1999 年に Schlegel は顕微鏡下精巣内精子回収術 (microdissection testicular sperm extraction：MD-TESE）によって精細 管の一部に精子形成があることを確認し, 精子が存 在する精細管の特徵として, 周囲より太く拡張し, や や白濁した内溶液が見えることを明らかにした ${ }^{2)}$ 。そ の後, MD-TESEは多くの施設で実施されるように なったが, 精子回収率は本邦では平均 40〜 $50 \%{ }^{3), 4)}$ と 海外の報告 $60 \%{ }^{5)}$ に比較すると成績は良くない。ま た，回収率の施設間差が大きく術者や設備により大 きな幅がある. その理由として, 精子が存在する精細 管を識別することの難しさがある.MD-TESEでは術 者 (医師) が顕微鏡下で精細管を視認しながら精子の 存在する部位の同定を試みるため, その成績は術者 の経験や技能に大きく依存する。言い換えれば, 客観 的で定量的な指標に基づいて精子が存在する精細管 を同定できる装置が構築できれば，精子回収率の向 上と施設間差の軽減が期待できる。そこで本研究で は, 精子が存在する精細管と存在しない精細管を識 別する視覚情報以外の指標として, 精細管の硬さの 違いに着目した。ヒト精巣の病理組織学的検討から Sato らは，造精機能が低下した精巣ではその程度に 相関して精細管基底膜が肥厚し，基底膜を構成する 細胞外基質の組成が一部変化していたことを報告し ている ${ }^{6)}$. 細胞外基質の組成が変われば精細管壁の物 性にも変化が生じると考えられ，また精子形成が不 良な精細管の内部では当然, 精子形成を担う細胞が 減少することから，精細管や精巣の硬さが変化する 可能性が高い.これらを踏まえ, 小川らの先行研究に より, カセンサレス臓器接触デバイスを用いて生体 内臓器の硬さを定量的に測定することに成功してい た7)ことをヒントに, この方法を応用し, 精細管壁の 硬さを測定することを着想した，以上の背景より， NOA 患者の精細管の精子が存在する部域と存在しな い部域では硬さに違いがあるとの仮説を立て, 硬さ の違いが, MD-TESEに扮ける精子回収部位同定の予
測因子になるのではないかとの発想に至った。

実際，がん組織や肝硬変は正常の組織より硬くな ることが知られており, 超音波による測定などが試 みられているが, 精細管のような $100 \mu \mathrm{m}$ 以下の局所 的なレベルでの測定法は開発されていない. 本研究 では, 定量的な硬さの指標として押し达み量と反力 の割合で表現される「剛性值」を採用し, ハムスター を用いた動物実験により, 正常な精巣と実験的に精 子形成不全を誘導した精巣の硬さを比較した。

\section{2. 精巣の力学的モデル化}

精巣は様々な構造体からなる複雑な器官である。 精巣が押し込み動作により变形するとき, 精巣白膜, 精細管, 間質などの複数の構造体によって反力が生 じる．これらの構造体を精巣を構成するサブシステ ムとして捉えたとき, 精巣に与える押し込み量が増 えると, 反力もサブシステムに依存して大きくなる。 すなわち, 精巣の反力は押しこみ量と押し达み速度 の関数として式（1）となる.

$$
F(x, \dot{x})=\sum_{i}^{n} f_{i}\left(x_{i}, \dot{x}_{i}\right)
$$

ここで, $F$ は精巣で生じる全反力, $f$ はサブシステ ムから生じる反力, $n$ はサブシステムの合計数であ る.ここで, それぞれの組織が剛性と粘性の性質を含 むと仮定すると, 反力の合計は式（2）として書き換 えられる。

$$
\begin{aligned}
F(x, \dot{x}) & =\sum k_{i} x_{i}+\sum d_{i} \dot{x}_{i} \\
= & \sum_{i}^{n} k_{i} c_{i}\left(X-x_{i}^{\operatorname{cog}}\right)+\sum_{i}^{n} d_{i} c_{i} \dot{X}
\end{aligned}
$$

ここで, $k_{i}$ は $i$ 番目のサブシステムの剛性, $d_{i}$ は $i$ 番 目のサブシステムの粘性, $x_{i}$ は $i$ 番目のサブシステム の変形量, $x^{\text {cog }}{ }_{i}$ は精巣とプローブの接触位置 $(\mathrm{X}=0)$ から $i$ 番目のサブシステムの重心位置までの垂直距 離, $x_{i}$ は $i$ 番目のサブシステムの押し込み速度, $X$ は 精巣の押し込み量, $\mathrm{X}$ は精巣への押し込み速度, $c_{i}$ は 式（3）で表す係数である.

$$
c_{i}= \begin{cases}1 & \left(X-x_{i}^{\operatorname{cog}} \geq 0\right) \\ 0 & \left(X-x_{i}^{\operatorname{cog}}<0\right)\end{cases}
$$

式（3）より, 各サブシステムの剛性と粘性は精巣 


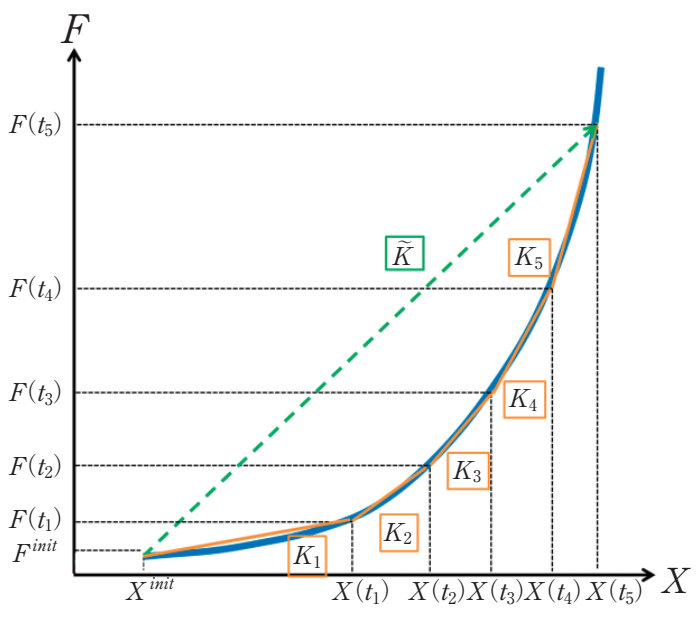

Fig.1 Relationship Between $K_{j}$ and $\widetilde{K}$

への押し込み量 $X$ に依存している. すなわち, 精巣 の剛性と粘性は精巣への押し込み量 $X$ の関数として 式（4）で表現される.

$$
F(X, X)=K(X) X+D(X) X
$$

ここで, $K(X)$ は非線形な剛性, $D(X)$ は非線形な 粘性となる。ここで, 精巣が低速で変形されるとき, 式（4）は式（5）に書き換えられる。

$$
F(X, X \approx 0) \approx K(X) X
$$

ここで, 非線形系である $K(X)$ を線形近似する。本 研究では, 剛性の変化量と精巣との接触時に発生す る初期剛性值と微小区間における剛性 $K_{j}$ の平均值と して式（6）で定義する。

$$
\widetilde{K}(X)=\frac{F^{i n i t}}{X^{i n i t}}+\frac{1}{m} \sum_{i=1}^{m} K_{j}
$$

ここで， $\widetilde{K}(X)$ は $K(X)$ を線形近似した值， $F^{\text {init }}$ 精巣との接触時に発生する反力, $X^{i n i t}$ は $F^{i n i}$ 測定時の 押し込み量, $j$ は微小区間の区間数, $m$ は最大押し込 み量 $X^{\max }$ の分割数である. また, 微小区間の剛性は押 し込みによる剛性の変化量を用いて式（7）で表すこ とができる。

$$
K_{j}=\frac{F\left(t_{j}\right)-F\left(t_{j-1}\right)}{X\left(t_{j}\right)-X\left(t_{j-1}\right)}
$$

ここで, $t_{j}$ は $j$ 番目の測定時間を表す。本研究では, $\widetilde{K}$ と $K_{j}$ を精巣の硬さの指標として用いる. Fig.1に最 大押し込み量を均等に 5 分割したとき $(m=5)$ の $\widetilde{K}$ および $K_{j}$ の関係困を記載する。

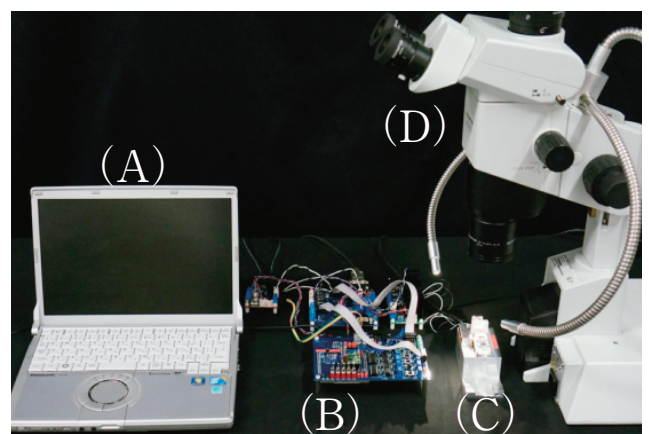

Fig.2a Whole System

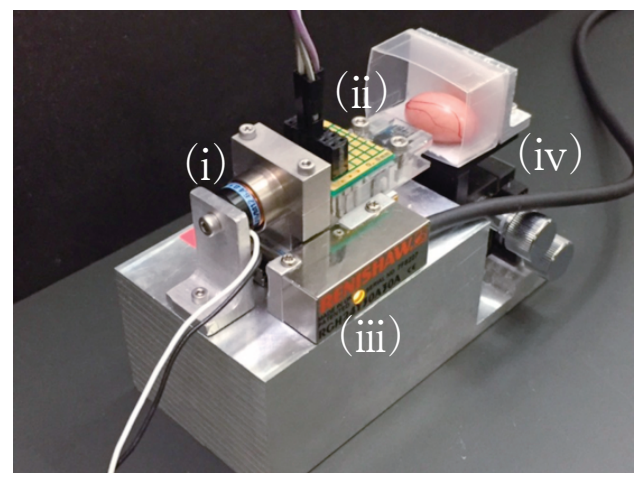

Fig.2b Measurement Device

Fig.2 System Configuration

\section{3. 方法}

\section{1 測定装置の構成と制御法}

Fig.2に実験装置を示した ${ }^{8)}$ 。測定系（Fig.2a）は 4 つのシステムにより構成され，（A）は制御用パソコ ン, （B）は制御システム[マイクロコンピュータ (STM32F411RET6 MCU, STMicroelectronics Co., Ltd), リニアアンプモータドライバ回路, カウンタ ボード, 13 ビットアナログデジタル変換回路], (C) は測定デバイス，（D）は顕微鏡である。同様に，測 定デバイス（Fig.2b）は 4つのシステムにより構成さ れ，（i ）は押し動作を実現するためのリニアモー夕 の一つであるボイスコイルモータ（voice coil motor : $\mathrm{VCM}$ ，（ii）は精巣反力を測定するためのマイクロ フォースセンサ（FTS-10000, Femto tools AG)，（iii） はVCMの位置を測定するためのリニアエンコーダ (RGH24, RENISHAW plc.)，（iv）は精巣の測定位置 の調整を行うための XZメカニカルステージ（XZmechanical stage, Misumi.Inc.) である. 測定中に精巣が乾 燥することを防ぐために, 精巣は生理食塩水で湿ら せた湿潤箱中に置いた状態で測定した。精巣は外乱 オブザーバ（Disturbance OBserver：DOB）を用いた位 置制御により測定した。 DOB は摩擦力や測定対象か 
Table 1 Control Parameters

\begin{tabular}{ll}
\hline Sampling Time & $0.1 \mathrm{msec}$ \\
\hline Nominal Mass of VCM $\left(M_{\mathrm{n}}\right)$ & $0.03 \mathrm{~kg}$ \\
\hline Nominal Torque Coefficient $\left(K_{\tau \mathrm{n}}\right)$ & $0.56 \mathrm{~N} / \mathrm{A}$ \\
\hline Position Gain $\left(K_{\mathrm{P}}\right)$ & $3600.0 \mathrm{~s}^{-2}$ \\
\hline Velocity Gain $\left(K_{D}\right)$ & $120.0 \mathrm{~s}^{-1}$ \\
\hline Cutoff Frequency of DOB $\left(g_{\text {dob }}\right)$ & $100 \mathrm{rad} / \mathrm{s}$ \\
\hline Cutoff Frequency of Pseudo Differentiation $\left(g_{\mathrm{pd}}\right)$ & $200 \mathrm{rad} / \mathrm{s}$ \\
\hline
\end{tabular}

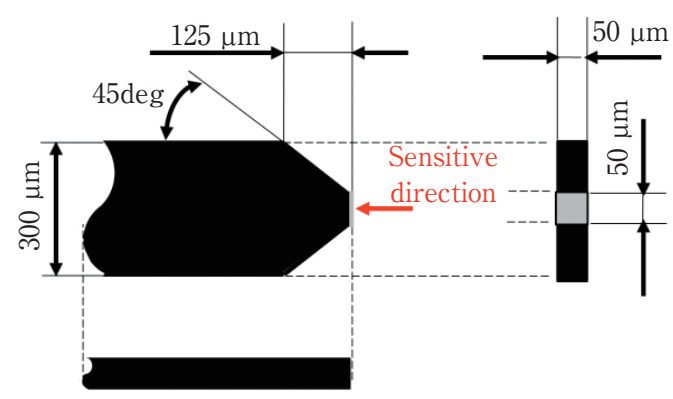

Fig.3 Shape of Force Sensor's Probe

ら生じる負荷のような外乱力を補償するためのオブ ザーバである ${ }^{9)}$. DOBを用いた位置制御の各パラ メータを Table 1 に示した。 マイクロフォースセンサ の仕様を Table 2 に記載した。マイクロフォースセン サのプローブにはシリコンが用いられている。精巣 はプローブの先端（50 $\mu \mathrm{m}$ の正方形平面）と接触し, プローブの歪み量から力を測定する.プローブの形 状に関する詳細について Fig.3に記載する. Fig.4 に測 定の様子を記載する。 センサのプローブを精巣表面 に接触した状態を初期位置（Fig.4a）とし, 精巣に対 し押し込みを開始し（Fig.4b）, あらかじめ指定した押 し込み量に達した時点で押し达み動作を停止した (Fig.4c)，なお，本研究でおこなったすべての実験に おいて, マイクロフォースセンサのプローブは精巣 を貫通しないことを顕微鏡下により確認した。
Table 2 Specifications of Force Sensor

\begin{tabular}{ll}
\hline Force Resolution $(10 \mathrm{~Hz})$ & $0.5 \mu \mathrm{N}$ \\
\hline Maximum Deformation of Measurement Tip & $1.5 \pm 0.5 \mu \mathrm{m}$ \\
\hline Sensor Force Range & $\pm 10000.0 \mu \mathrm{N}$ \\
\hline Stiffness of Measurement Tip & $6666.7 \mu \mathrm{N} / \mu \mathrm{m}$ \\
\hline Sensor Gain & $5000.0 \mu \mathrm{N} / \mathrm{V}$ \\
\hline Resolution of AD Convertor & 13 bit \\
\hline
\end{tabular}

\section{2 精巣の力学モデルの妥当性に関する検証法} 本研究では, 式 (4) で定義したと抢り, 精巣は剛 性と粘性を含む物質と仮定している. そこで, 剛性と 粘性の影響について確認するために式（8）によって 定義される機械インピーダンス $G(X, X)$ を用いて 2 通 りの検証を抢こなった。

$$
\frac{F(X, X)}{X}=G(X, X)
$$

検証のための実験には, オスの成熟シリアンハム スターより摘出した精巣 $(\mathrm{n}=3)$ を用いた.

\section{1）粘性に対する依存性の確認}

一定の押し込み量で等速度試験をおこない, 粘性 の影響について検証した. 4 通りの速度指令值（ $X_{1}^{\text {cmd }}$ $=10.0, X_{2}^{c m d}=50.0, X_{3}^{c m d}=100.0, X_{4}^{c m d}=500.0$ 単位 : $\mu \mathrm{m} /$ $\mathrm{sec})$ でVCM を制御した。 反力は押し込み動作中にマ イクロフォースセンサによって測定した。 また, 押し 込み量は $500 \mu \mathrm{m}$ で一定とし, 押し込み量が $500 \mu \mathrm{m}$ に 達したときに発生する瞬時反力について各押し込み 速度ごとに測定し, 機械インピーダンスを算出した。

\section{2）剛性に対する依存性の確認}

一定の押し込み速度で等速度試験をおこない, 剛 性の影響について検証した。押し込み速度を $10.0 \mu$ $\mathrm{m} / \mathrm{sec}$ で一定とし, 5 通りの位置指令值 $\left(X_{1}^{c m d}=400.0\right.$, $X_{2}^{\text {cmd }}=800.0, X_{3}^{\text {cmd }}=1200.0, X_{4}^{\text {cmd }}=1600.0, X_{5}^{\text {cmd }}=2000.0$ 単位： $\mu \mathrm{m})$ でVCM を駆動し, 各位置指令值に対す

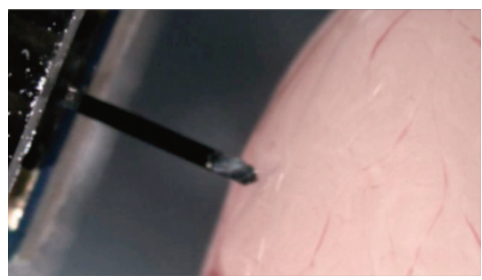

Fig.4a Initial Position

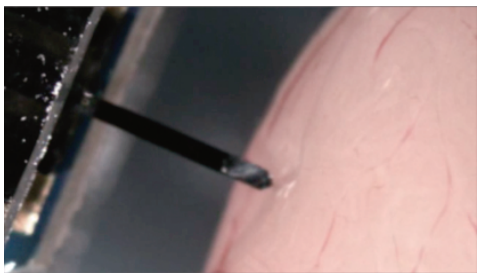

Fig.4b Pushing

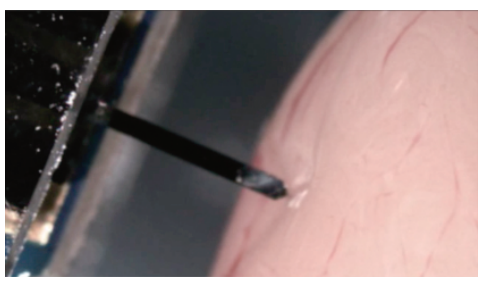

Fig.4c Finish

Fig.4 Measurement Motion 


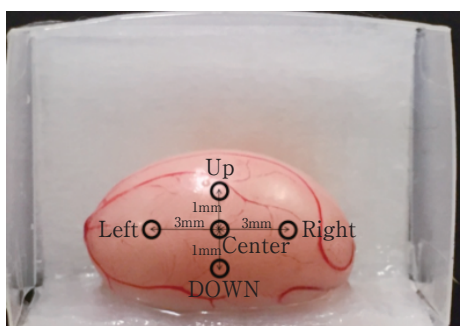

Fig.5 Measurement Point

る反力を測定した. 押し込み量と反力の結果から, 機 械インピーダンスを算出した。

\section{3 精子形成不全ハムスターの作製}

11〜14 週令の成熟したオスのシリアンハムスター に実験的停留精巣手術を施し, 精子形成不全を誘起 した．イソフルラン (和光純薬) 吸入麻酔下にて左側 精巣を腹腔内に引き上げて固定し ${ }^{10)}, 2$ 週間後に摘出 した精巣について各種測定および病理学的評価をお こなった。左側を停留精巣 (cryptorchidism, Crypt) 群 とし, 右側の未処置精巣を対照 (Control) 群とした.

\section{4 精巣の硬さ測定と精子形成能の病理学的評 価}

測定に用いる精巣は，炭酸ガスによる安楽死後の ハムスターより摘出し, 脂肪組織などを取り除いた あと，測定まで蓋付きプラスチックシャーレに入れ て $4^{\circ} \mathrm{C}$ で保存した．精巣の硬さは押し込み試験の際の プローブの接触角度の差や精巣内部域差の影響を考 慮して，精巣の 5 か所について測定した（Fig.5）。水 平方向および垂直方向位置の調整は XZメカニカル ステージを用いておこない, 中央, 右, 左, 下，上の 順番で測定した。押し込み量は $500 \mu \mathrm{m}$ ，押し込み速 度は $10.0 \mu \mathrm{m} / \mathrm{sec}$ で一定とした。

測定後の精巣をブアン液にて固定後, パラフィン 包埋標本を作製し，HE染色をおこなった，精子形成 の成熟度を形態から定量的（1 から 7) に評価する Johnsen スコア (JS) ${ }^{11)}$ を用いて，ランダムに 30 の精 細管断面を評価し，平均スコアを JS 值とした。 JS は ヒトの精巣の精子形成能評価のために作成された基 準であるが，ハムスターはヒトと精子形成の様相が 異なるため，JS をハムスターに適用するためにスコ アリングの基準を一部改変した。すなわち score 5 以 下についてはヒトの基準をそのまま適用し，精子細 胞の成熟度が円形精子細胞までを score 6, 初期伸長

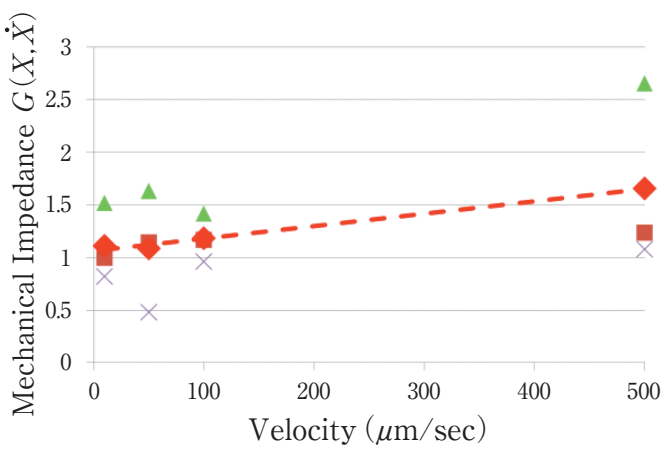

Fig.6a Dependency of Pushing Velocity

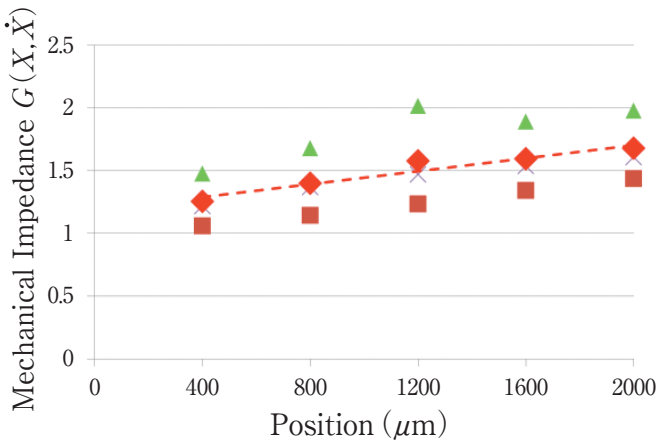

Fig.6b Dependency of Deformation Amount

$$
\begin{aligned}
& \Delta \text { Testis-A } \times \text { Testis }-\mathrm{C} \\
& \square \text { Testis-B Average } \\
& \text { - - - - Linear Approximation of Average }
\end{aligned}
$$

Fig.6 Experimental Results for Physical Model Validation.

精子細胞までを score 6.5, 後期伸長精子細胞までを score 7.0 とし最高スコアとした.

\section{5 統計学的解析}

統計学的解析には JMP ver. 12（SAS Japan）を用い た. 多群間の比較には分散分析, 対応のある 2 群間の 比較には paired t-test を用い, 有意水準を $5 \%$ とした。

\section{4. 結果}

\section{1 精巣のカ学モデルの妥当性に関する検証 1）粘性に対する依存性}

Fig.6aに押し込み速度を変えて精巣の反力を測定 したときの機械インピーダンスの変化を示した。測 定結果より，押し込み速度が速いほど機械インピー ダンスが大きくなることがわかった，押し込み量が 一定のため，機械インピーダンスの増分は粘性によ り生じたものと考えられる。すなわち, 本実験で扱う 精巣は粘性をもつことが示された. しかし, 押し込み 速度が低速域 $\left(X^{c m d}=10.0 \sim 100.0\right)$ での反力の変化量 
に大きな変化がみられないことから，低速域につい ては粘性の影響を無視できることが明らかになった。

\section{2）剛性に対する依存性}

Fig.6bに押し込み量を変えて精巣の反力を測定し たときの機械インピーダンスの変化を示した，測定 結果より, 押し込み量が増えるほど, 機械インピーダ ンスが大きくなることがわかった，押し込み速度が 一定のため, 反力の増分は剛性により生じたものと 考えられる。剛性が線形の場合, 剛性の大きさは押し こみ量に依存せずに一定となるため，本実験で扱う 精巣は非線形な剛性を有すると考えられる。そのた め, 剛性の非線形性については式（8）により得られ る微小区間ごとの剛性值 $K_{j}$ を用いて線形近似するこ とで定量的な測定值であるとみなした.

\section{2 精巣の硬さ測定値の測定回による変動の検 討 \\ 測定回による測定值の変動の有無を検証するため}

Table 3 Results of Average Stiffness for each experiment

\begin{tabular}{ccc}
\hline Day & $\mathrm{n}$ & $\widetilde{K}(\mu \mathrm{N} / \mu \mathrm{m})$ mean $\pm \mathrm{SD}$ \\
\hline $1 \mathrm{st}$ & 2 & $1.674 \pm 0.458$ \\
2nd & 3 & $1.432 \pm 0.335$ \\
3rd & 3 & $1.594 \pm 0.271$ \\
4th & 7 & $1.354 \pm 0.288$ \\
\hline Total & 15 & $1.460 \pm 0.313$ \\
\hline
\end{tabular}

Table 4 Results of Average Stiffness for each measurement point

\begin{tabular}{lccc}
\hline \multirow{2}{*}{ Point } & $\mathrm{n}$ & \multicolumn{2}{c}{$\tilde{K}(\mu \mathrm{N} / \mu \mathrm{m})$} \\
\cline { 3 - 4 } & & mean $\pm \mathrm{SD}$ & range \\
\hline Center & 43 & $1.041 \pm 0.572$ & $0.218-2.266$ \\
Right & 43 & $1.051 \pm 0.575$ & $0.187-2.185$ \\
Left & 43 & $1.039 \pm 0.583$ & $0.163-2.109$ \\
Bottom & 43 & $1.096 \pm 0.642$ & $0.200-2.398$ \\
Upper & 43 & $1.008 \pm 0.601$ & $0.195-2.280$ \\
\hline Total & 215 & $1.047 \pm 0.589$ & $0.163-2.398$ \\
\hline
\end{tabular}

に, Control 群について 4 回の異なる測定日の平均 $\widetilde{K}$ 值を比較した（Table 3). 4 回の平均值に有意差はな く $(p=0.5341)$, 複数回における剛性測定值を比較す る際に測定回による差を考慮する必要がないことが 示された。

\section{3 精巣の測定部位による硬さ測定值の検討}

押し込み試験をおこなった精巣 5 か所の部位にお ける $\widetilde{K}$ 值を Table 4 に示した. 対応のある $\mathrm{t}$ 検定の結 果, 5 か所の $\widetilde{K}$ 值どの組み合わせにも平均值に有意な 差はみられなかった。この結果から, 以降は 5 か所の 平均 $\widetilde{K}$ 值を剛性值として使用することとした.

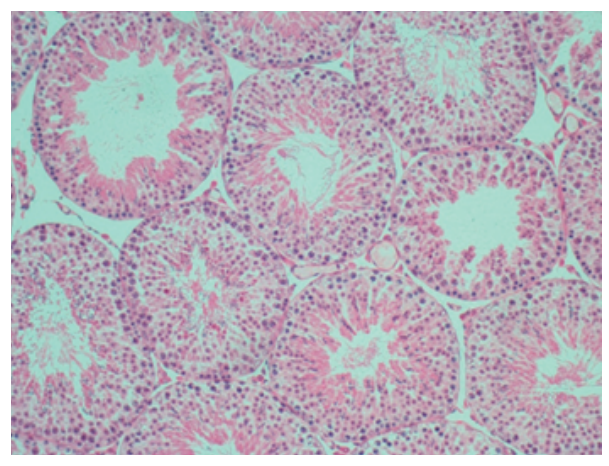

Fig.7a Control

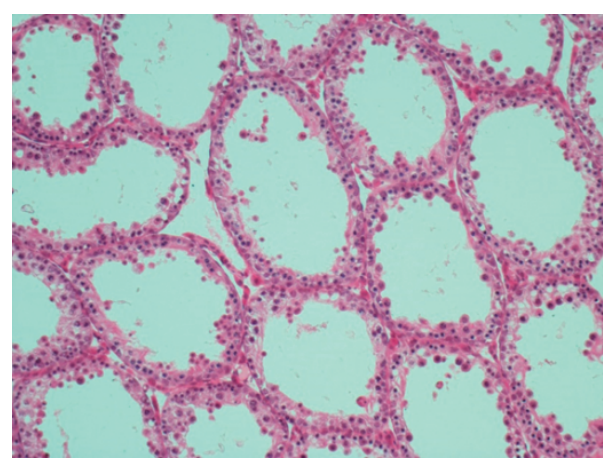

Fig.7b Crypt

Fig.7 Histopathological Images of the Hamster Testis

Table 5 Comparison the Results Between Control Group and Crypt Group

\begin{tabular}{|c|c|c|c|c|c|}
\hline \multirow{2}{*}{ Parameters } & \multicolumn{2}{|c|}{ Control $(n=15)$} & \multicolumn{2}{|c|}{ Crypt $(n=16)$} & \multirow{2}{*}{$p^{\text {-value }}$} \\
\hline & mean $\pm \mathrm{SD}$ & range & mean $\pm \mathrm{SD}$ & range & \\
\hline Testis weight $(\mathrm{mg})$ & $1.86 \pm 0.15$ & $1.52-2.08$ & $0.614 \pm 0.118$ & $0.42-0.89$ & $<0.0001$ \\
\hline Testis size : major axis $(\mathrm{mm})$ & $20.9 \pm 0.80$ & $19-22$ & $15.2 \pm 1.22$ & $13-18$ & $<0.0001$ \\
\hline minor axis $(\mathrm{mm})$ & $14.7 \pm 0.70$ & $14-16$ & $10.4 \pm 1.15$ & $8-13$ & $<0.0001$ \\
\hline$\widetilde{K}(\mu \mathrm{N} / \mu \mathrm{m})$ & $1.46 \pm 0.31$ & $1.01-2.00$ & $0.40 \pm 0.13$ & $0.24-0.68$ & $<0.0001$ \\
\hline Johnsen score $(1-7)$ & $6.96 \pm 0.04$ & $6.9-7.0$ & $4.08 \pm 0.71$ & $2.93-5.43$ & $<0.0001$ \\
\hline
\end{tabular}




\section{4 精子形成不全ハムスターにおける精巣の硬 さ測定と各種パラメータの比較}

実験的停留精巣手術 2 週間後のハムスター精巣に は明らかな精子形成不全が認められた（Fig.7）。Control 群と Crypt 群における各種パラメータと $\widetilde{K}$ 值, JS を Table 5 に示した。精巣重量, 精巣長径, 精巣短径, $\widetilde{K}$ 值，JS の全てにおいて，Crypt群で有意に低下して いた。すなわち停留精巣手術によってハムスター精 巣は精子形成能が低下し, その精巣においては剛性 值も低下していることが明らかになった。

\section{5 精子形成不全ハムスターにおける精巣の各 微小区間の剛性値 $\boldsymbol{K}_{\boldsymbol{j}}$}

全押し込み量を 10 等分 $(m=10)$ して, 各微小区 間の剛性值（Kj值）について, Control 群と Crypt 群の 比較をおこなった（Fig.8）。点線は各微小区間の剛性 值の平均值を直線で結んだ回帰直線である。測定結 果より, Control 群の精巣では微小区間数が増加, つ まり押し込み量の増加とともに剛性の值が高くなる $(y=0.053 j+1.16)$ が, Crypt 群では，押し込み量が増 加しても剛性值はほとんど増加しない $(y=0.0072 j+$ 0.4983）ことがわかる。この結果は, 回帰直線の傾き からも理解できた。

\section{5. 考察}

本研究では, 精子の存在する精細管部位を同定す るためのコンピュータ支援による測定装置の開発を 目指し，その第一段階として精巣の硬さ測定装置を 開発し，測定装置の有用性を検証することを目的と して, 精子形成能不全八ムスターの精巣の硬さを測 定した。実際, 生体組織の硬さの変化は多くの医療分 野で注目されている。例えば, がん組織や肝硬変は正

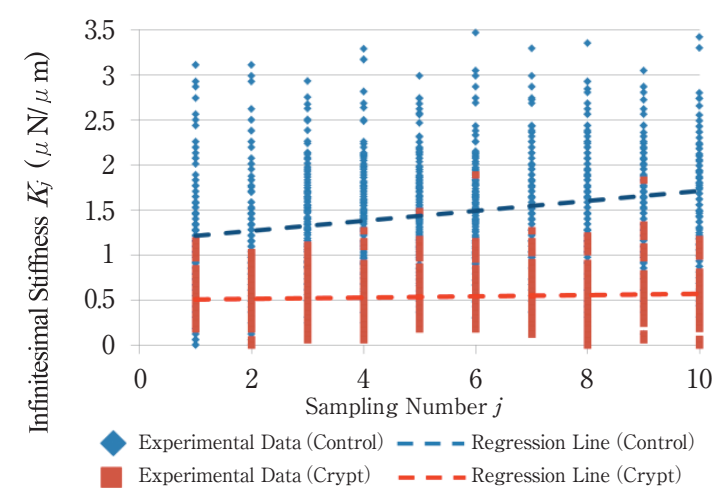

Fig.8 Measurement Results of $K_{j}$ Value
常の組織より硬くなる。その測定には多くの方法が あるが, なかでも超音波による測定は医療分野で最 も実績のある手法である ${ }^{12), 13)}$. しかし超音波法には, 超音波の放射範囲により硬さの值が変化するという 問題点があり，ごく小さな特定の箇所の測定には適 していない，本法においてはVCMに位置制御を実装 することで精巣への押し込み動作を扔こない, マイ クロフォースセンサを用いて, 押し込み時に精巣か ら生じる反力を測定する装置を新たに開発した。位 置制御に DOB を組み合わせることで, 未知の外乱を 補償することができ, 精巣に対して正確に押し込み を拀こなうことができる，さらに，硬さの定量的な判 定のために,「剛性值」を用いて評価を㧍こなった。 2 通りの剛性值を用いることで, 精巣の静的な性質 (剛性の平均值: $\widetilde{K}$ ) と動的な性質（剛性の微小変化： $\left.K_{j}\right)$ をそれぞれ確認することが可能であった，その方 法として精巣の力学的なモデル化を执こない, モデ ルの妥当性について実験により検証したのち, 正常 および精子形成不全をきたした精巣を比較して, 硬 さによる精子形成能の定量的評価が可能であるかを 統計学的に検討した，その結果, 精子形成能の低下し た精巣では $2 つ の$ 剛性值である $\widetilde{K}$ および $K_{j}$ 值がどち らも有意に低下していることが示された，精巣にお ける精子形成能を評価する方法としては, 病理組織 標本を作製して判定する以外の方法は殆ど知られて おらず，本研究のように精巣そのままを測定対象と して質を定量的に評価する試みは, 我々の知る限り 初めての報告である.

本研究では押し込み速度㧍よび押し込み量を 10.0 $\mu \mathrm{m} / \mathrm{sec}$ と $500.0 \mu \mathrm{m}$ に設定した. Fig.4a の結果から精 巣の粘性が押し込み速度の増加に伴い大きくなるこ とが理解できるため, 押し込み速度による粘性值の 増加を抑える必要がある. 本研究では, 低速域での粘 性の増加の差が少ないことから, 測定に時間のかか らない範囲で速度が大きくなりすぎない值として 10 $\mu \mathrm{m} / \mathrm{sec}$ に設定した。同じく, Fig.4b の結果より，押 し込々量の増加に伴い, 剛性の值が大きくなること が実験結果から理解できたため, 精巣を確実に押し 込むことのできる範囲で押し込み量が大きくなりす ぎない $500 \mu \mathrm{m}$ に最大押し込み量 $X^{\max }$ を設定した。ま た, 白膜の厚さは $25 \sim 30 \mu \mathrm{m}$ であり, 押し込み量に比 べ精巣白膜の厚さが十分に小さく, 精細管などのサ ブシステムから生じる反力も測定した反力に反映し ていると考えられる。 
本研究で用いたマイクロフォースセンサはプロー ブの接触面が $50 \mu \mathrm{m}$ 四方の正方形平面となっている. この形状のプローブを採用することで，精巣白膜を プローブが貫通することを防ぐことができる。さら に，プローブの接触面積は精巣全体の断面積よりも 十分小さいので精巣とプローブで接触時に発生する 摩擦力を限りなく小さくすることができると考えら れ，マイクロフォースセンサの形状が本研究を遂行 する上で適切であるとして採用した。

微小剛性值 $K_{j}$ について考察すると, Fig. 6 より Control 群では押し込み量の増加に伴い $K_{j}$ 值が増加してい るが, Crypt 群では押し込み量が増加しても $K_{j}$ 值が増 加せず, ほぼ一定の值をとることが判明した。この違 いを考察すると, Crypt群ではControl 群に比べて精巣 を構成するサブシステムの密度が低下したことが原 因と推察される。その要因として Fig.7bにみられる ような精子形成能不全に基づくサブシステムの病的 変化, 例えば精細管の縮小による間質占有率の増加, 精細管基底膜の厚さおよび性質変化, 精細胞層の菲 薄化による精細管内腔の増大などが考えられる。本 研究ではそれら原因の特定にまでは至らなかったが, さらなる病理組織学的な検討により明らかにできる 可能性がある。

今後の課題として, MD-TESEにおける実用化のた めには精細管単位で硬さを測定する必要があるが, より分解能の高いマイクロフォースセンサを実装す ることで本装置が精細管レベルでの硬さ測定にも応 用できることをすでに予備的検討により確認してい る. 現在MD-TESEにおいては精巣から採取した数本 の精細管の束を肧培養士がすりつぶし，顕微鏡下に 内容物の精子の有無を確認する方法がとられている が, 本研究が発展して精細管の硬さを定量的に評価 することが可能となれば，精巣から精細管を採取す ることなく精子が存在する精細管の同定ができるた め, 不用な組織を採取することを回避できる。このよ うに, MD-TESE 術中にリアルタイムに精子の存在箇 所を特定することができれば，術者間差や施設間差 の減少のみならず, 精子回収率を含めたMD-TESE技 術の向上に大いに貢献できると考えられる。ささらに, 本法における定量的な測定に加えて, 飯田, 大西らの 発明による haptics 技術 ${ }^{14)}$ を適用し，マスタ，スレー ブロボット間で位置と力の情報を同期することで, 医師はロボットを経由して精細管の硬さを感じなが ら TESEをおこなうことが可能になり, 極めて画期的
な治療法が実現する。

\section{謝辞}

本研究の一部は日本学術振興会科学研究費補助金 (課題番号 $15 \mathrm{~K} 15588$ 挑戦的萌芽研究「haptics 技術を 用いた非閉塞性無精子症に対する精巣内精子回収術 の新展開」)によっておこなわれたことを記すと共に, 関係者各位に謝意を表す。さらに, 本研究掲載の経費 は, 文部科学省補助事業『慶應義塾大学リーディング 大学院 (オールラウンド型) 超成熟社会発展のサイエ ンス』によってサポートされている.

\section{文献}

1) Su LM, Palermo GD, Goldstein M, et al. Testicular sperm extraction with intracytoplasmic sperm injection for nonobstructive azoospermia : testicular histology can predict success of sperm retrieval. J Urol $1999 ; 161: 112-116$.

2) Schlegel PN. Testicular sperm extraction: microdissection improves sperm yield with minimal tissue excision. Hum Reprod 1999 ; $14:$ 131-135.

3) Okada H, Dobashi M, Yamazaki T, et al. Conventional versus microdissection testicular sperm extraction for nonobstructive azoospermia. J Urol $2002 ; 168$ : 1063-1067.

4) Tsujimura A, Matsumiya K, Miyagawa Y, et al. Prediction of successful outcome of microdissection testicular sperm extraction in men with idiopathic nonobstructive azoospermia. J Urol 2004 ; 172: 1944-1947.

5) Schlegel PN. Nonobstructive azoospermia : a revolutionary surgical approach and results. Semin Reprod Med $2009 ; 27$ : 165170.

6) Sato Y, Nozawa S, Iwamoto T. Study of spermatogenesis and thickening of lamina propria in the human seminiferous tubules. Fertil Steril $2008 ; 90:$ 1310-1312.

7）小川健司, 魚住誠二, 青 浩洋 ほか. 力センサレス臟器触 診デバイスによる生体の硬さ測定法. JJSCAS 2015；17： 91-100.

8）冨塚大輔, 小川健司, 吉池美紀 ほか. 精子形成能判定の ための精巣の硬さ測定装置の開発〜ハムスター精巣を用 いての検討〜. JJSCAS 2016；18；271-272.

9) Ohnishi K. Robust Motion Control by Disturbance Observer. Journal of Robotics and Mechatronics $1996 ; 8: 218-225$.

10) Shirai M, Matsushita $S$, Kagayama M, et al. Histological changes of the scrotal testis in unilateral cryptorchidism. Tohoku J Exp Med 1966 ; $90: 363-373$.

11) Johnsen SG. Testicular biopsy score count-a method for regis- 
tration of spermatogenesis in human testes : normal values and results in 335 hypogonadal males. Hormones $1970 ; 1: 2-25$.

12) Nakamura M, Ikezoe T, Kobayashi T, et al. Acute effects of static stretching on muscle hardness of the medial gastrocnemius muscle belly in humans : an ultrasonic shear-wave elastography study. Ultrasound Med Biol $2014 ； 40$ : 1991-1997.

13) Matsuzuka T, Suzuki M, Saijo S, et al. Stiffness of salivary gland and tumor measured by new ultrasonic techniques : Virtual touch quantification and IQ. Auris Nasus Larynx 2015; 42 : 128-133.

14) Iida W, Ohnishi K. Reproducibility and operationality in bilateral teleoperation. The $8^{\text {th }}$ IEEE International Workshop on Advanced Motion Control. 2004. AMC '04. 2004 ; 217-222. 